\title{
SZIGMOID GÖRBÉK ALKALMAZÁSA TANULÓCSOPORTOK EREDMÉNYEINEK VIZSGÁLATÁHOZ
}

\author{
Rézsó Ferencné \\ mesteroktató, Miskolci Egyetem, Gép-és Terméktervezési Intézet \\ 3515 Miskolc, Miskolc-Egyetemváros, e-mail: machbk@uni-miskolc.hu
}

\begin{abstract}
Absztrakt
A Gépészmérnöki alapismeretek c. tantárgy egyik zárthelyi dolgozatát megíró két hallgatói csoport eredményeit dolgoztuk fel és hasonlitottuk össze. Az eredmények alapján a csoportokra „ujjlenyomat” szerüen jellemzö szigmoid görbéket lehet létrehozni, melyeknek képezhetö a deriváltja és integrálja, valamint a szigmoid görbék egyenlete is felírható. Az egyenletek megalkotásához approximációs eljárásra van szükség, ehhez a Nelder-Mead optimumkeresö algoritmust alkalmaztuk. A görbék lefutása, az egyenletekben szereplö paraméterek számértékei alapján sok apró részletre kiterjedö, számszerüsithetö jellemzés készithetö egy adott csoport eredményeiröl, teljesítményéröl. Ezeknek a jellemzéseknek, számértékeknek az összehasonlitása objektiv, részletes, számszerüen alátámasztható, több szempontot figyelembe vevö minösitéseket, rangsorolásokat tesz lehetövé, valamint rávilágit a csoport tagjainak a felkészitö tanár, vagy az értékelö számára fontos jellemzöire is. A cikkben bemutatott eredmények hasznosak lehetnek a minöségbiztositás területén is.
\end{abstract}

Kulcsszavak: Szigmoid görbék, csoportok teljesitménymérése, összehasonlitása, életgörbék

\begin{abstract}
The results and achievements of two student groups, writing the same test of the topic „Fundamentals of mechanical engineering" were studied and compared. On the basis of these results it is possible to build characteristic sigmoid curves of the groups. These curves are unique for the given group, just like fingerprints for humans. After writing the equations of these curves, it is possible to create the derivatives and integrals of the curves. For the approximation process the Nelder-Mead optimization algorithm is used. Investigating the shape of the curves and the numerical values of the parameters in the equations of the curves, a very detailed, numerically documented characterization can be made about the results and achievements of a group. Comparison of these characterizations will reveal some very important characteristics of the group members which can be important for the teacher or for persons evaluating or monitoring the groups and makes possible to create objective, detailed, numerically documentable ranking or qualification of the groups, which will take into consideration several important points of view.
\end{abstract}

Keywords: Sigmoid curves, measuring and comparing achievements of groups, life curves

\section{Bevezetés}

A növekedési vagy telítődési jelenségeket leíró, S-alakot formázó görbéket szigmoid (azaz s- jellegü) görbéknek is nevezik. Ezek a görbék az élet számos területén használatosak az ilyen jelenségek leírására, tanulmányozására, sőt ezek alapján trendek is azonosíthatók, vagy egy jelenség jövőbeli alakulására vonatkozó kijelentések, következtetések is megfogalmazhatók. Ezeket a görbéket akár méltán nevezhetnénk multidiszciplináris görbéknek is, mivel számos tudományterület vizsgálatakor találkoz- 
hatunk velük (biológia - populációdinamika, közgazdaságtan - termékek életciklus görbéje, orvostudomány - daganatok növekedése, környezetvédelem - légköri szennyezés és tengerek mủanyagszennyezettsége, agrár alkalmazások - halállományok növekedése, erdőgazdálkodás, optimum kereső algoritmusok iterációtörténeti függvénye). A szigmoid görbékkel végzett vizsgálatokra számos példát találhatunk a szakirodalomban.

A szigmoid görbék felfedezése és vizsgálata az 1700-as évek végére tehető, Malthus (1798) [1] munkásságához kapcsolódóan, aki azt mondta ki, hogy bármilyen biológiai faj (így az ember is) létszámának pillanatnyi növekedése függ attól, hogy éppen mennyi az aktuális létszám, azaz

$$
\dot{N}=f(N)
$$

Bevezette a belső növekedés üteme nevü paramétert (növekedési ráta):

$$
\dot{N}=r N ; \quad r=\frac{\dot{N}}{N}
$$

Ha r értéke állandó, akkor a populáció időbeli növekedését leíró függvény alakja a következő:

$$
N(t)=N_{0} e^{r t}
$$

Ez a képlet nagy térségekben, zavartalanul szaporodó fajokra igaz. Napjainkban az ilyen növekedésre ad példát Gordon E. Moore 1965-ös, a számítógépek kapacitásának 1,5 évenkénti megduplázódására vonatkozó törvénye [2], vagy az internet felhasználók számának növekedése.

Az exponenciális növekedési ütem azonban nem tartható fenn zavartalanul hosszú távon. Pierre- Francois Verhulst belga matematikus (1847) [3] megoldotta azt az esetet, amikor a populációknak van egy bizonyos szaturációs (telítődési) szintje, K . Kimutatta, hogy ekkor a növekedést leíró egyenlet alakja:

$$
\dot{N}=r N\left(1-\frac{N}{K}\right)
$$

és bevezette a logisztikus növekedés fogalmát. Ha N kicsi, akkor az (1 - N/K) szorzó értéke közel 1 , ekkor az exponenciális növekedéshez hasonló a viselkedés. Ha $\mathrm{N}$ értéke növekszik, akkor a szorzó értéke egyre kisebb, ha 0 értéket vesz fel, akkor a növekedés leáll, azaz a populáció létszáma egy konstans értéken állandósul, ami a szaturáció, vagy telítődés jelensége. Ez a korlátozott térben lezajló növekedési folyamatok modellje. Pearl és Reed szerzőpáros 1920-ban az USA népességének elörejelzésére [4] használta és felelevenítette a logisztikus növekedés vagy logisztikai görbe elnevezéseket. A (4) egyenletet kielégítö logisztikai görbe egyenlete:

$$
N(t)=\frac{K}{1+e^{-r t-b}}
$$

A görbe $\mathrm{S}$ alakja alapján honosodott meg a szigmoid (s- alakú) görbék elnevezés. Az (5) egyenletben szereplö $b$ paraméter a görbe idő tengelyen való elhelyezkedését befolyásoló úgynevezett helyzetparaméter, a görbe alakját nem befolyásolja. Ha r értéke pozitív, akkor logisztikus növekedésről beszélünk, ha negatív, akkor logisztikus csökkenésröl van szó. 
A szigmoid görbék közelítésekor szükség van a regressziós együttható számítására, hogy látható, számszerüsíthető és ellenőrizhető legyen a közelítés jósága. A regressziós együtthatót lineáris közelítés esetére a legkönnyebb kiszámolni, ezért célszerü az $\mathrm{S}$ alakú görbét olyan transzformációnak alávetni, amivel az alakja egyenessé alakítható, például a logaritmus alkalmazásával. Egy ilyen trtanszformációt dolgozott ki Fisher és Pry (1971) [5]. A Fisher- Pry transzformáció lényege, hogy alkalmazva a $\mathrm{F}=\mathrm{N} / \mathrm{K}$ transzformációt, akkor $\ln (\mathrm{F} /(1-\mathrm{F}))=\mathrm{rt}+\mathrm{b}$, tehát a logisztikus függvény helyett egy egyenest kapunk, melynek meredeksége $\mathrm{r}$. Az egyenesre pedig már könnyen kiszámítható a regressziós együttható.

Olyan esetekre, amikor a növekedési folyamat során a kezdeti időszakban sem exponenciális a növekedés, Bertalanffy (1938) végzett vizsgálatokat [6] és létrehozta a Bertalanffy-féle növekedési görbét, amit cápák testhosszának növekedési üteme vizsgálatára használt. Később kiderült, hogy ez a görbe haszonnal alkalmazható különféle halállományok vizsgálatára és az erdőgazdálkodásban is, 2003-ban pedig Kozuko és társai [7] az orvostudományban daganatos sejtek szaporodásának vizsgálatára alkalmazták. A Bertalanffy függvény egyenlete:

$$
N(t)=K-\left(K-N_{0}\right) e^{-r t}=K\left(1-\frac{K-N_{0}}{K} e^{-r t}\right)
$$

Richards 1959-ben [8] a Bertalanffy görbét módosította és a növények növekedésének vizsgálatára is alkalmassá tette.

A szigmoid görbék közgazdaságban, iparban és terméktervezésben, termékek bevezetésének, életciklusának vizsgálatában való alkalmazhatóságát teszik lehetővé Mansfield (1961) [9] és Rogers (1962) [10] eredményei az innovációk terjedésének és az ipari technológiai eljárások bevezetési sebességének vizsgálataira vonatkozóan. Jang, Show- Ling és munkatársaik (2005) [11] kevert modell létrehozásával 29 OECD ország és Tajvan esetében vizsgálták a mobiltelefonok elterjedését, mely szintén szigmoid függvényre vezetett.

Meyer (1994) [12] arra hívta fel a figyelmet, hogy létezhetnek olyan pulzáló folyamatok, amikor egy növekedési folyamatra épülve egy újabb kezdődik (bi- logisztikus, tri- logisztikus, multi- logisztikus növekedés). Erre épül Silverberg és Lehnert (2003) munkája [13] az evolúciós gazdasági növekedés modelljére vonatkozóan. A szigmoid görbék társadalomtudományi jelenségekre való alkalmazására érdekes példákat találhatunk Nikosz (2009) munkájában [14].

A szigmoid görbéket, deriváltjaikat és integráljukat Szabó többféle területen is alkalmazza : Kimutatta, hogy a különböző sportágak világcsúcs- eredményinek száz éves történetét bemutató görbe szintén szigmoid görbe (2011) [15], valamint értelmezte a különböző technikai fejlesztéseknek az eredmények görbéjére gyakorolt hatását. A szigmoid görbék tulajdonságainak, az egyenletekben szereplö paramétereknek, a görbék deriváltja, integrálja vizsgálatával (2017) [16] egy szempontrendszert fejlesztett ki (EBSYQ, Evolutionary Based System for Qualification of Group Achievements, azaz csoportok teljesítményének evolúciós alapú összehasonlító és minősítő módszere), amely objektív, jól számszerüsíthető módon, finom különbségeket is kimutatva lehetővé teszi különböző tanulói csoportok, vagy támogatásra jelentkezők, állásinterjún résztvevők, egymással versengő csoportok minősítését, rangsorolását. A módszer széleskörü alkalmazhatóságát mutatja, hogy hatékonyan alkalmazható optimumkereső algoritmusok, módszerek összehasonlításához is (2018) [17], vagy ugyanazon módszer többféle beállításainak összehasonlítására, miközben nem szükséges a módszer többszöri futtatásának elvégzése, a futásidő többszöri végigvárása, hanem a görbék korai szakasza alapján történő közelítések felhasználásával ennek az időnek kétharmada is megtakarítható. Ez a multidiszciplináris 
optimálás korszakában esetleg több nap időnyereséget is eredményezhet. Szintén a szigmoid görbék multidiszciplinaritását, rugalmasságát emeli ki, hogy a világ és Európa műanyag- gyártásának utóbbi évtizedekre vonatkozó görbéjét vizsgálva, amelyek szintén szigmoid jelleget mutatnak, becslést és jövőképet ad (2019) [18] a tengerek, óceánok müanyag-szennyezettségének jövőbeli alakulásáról. Szabó az említett vizsgálatokhoz kifejlesztett egy közelítési módszert, melynek során a görbék legkisebb négyzetek elve szerinti közelítését optimumkeresési problémaként írja fel, melyben a célfüggvény az eltérések összege, aminek a minimumát keressük, a változók pedig a szigmoid görbék egyenletében szereplő $K, r, b$ paraméterek, melyeknek a Nelder- Mead [19] optimumkereső algorimussal keresi meg a legkisebb eltéréseket adó értékeit. Ennek során a Fisher- Pry transzformációt is felhasználja, így a közelítés jóságának ellenőrzéséhez megadja a regressziós együttható értékét is. A regreszsziós együttható értékének összehasonlításából az is eldönthető, hogy a vizsgált jelenség viselkedése inkább a logisztikus függvényhez, vagy esetleg a Bertalanffy függvényhez van-e közelebb.

Jelen munkában az EBSYQ módszer szempontrendszerét alkalmazva egyetemi hallgatók csoportjait hasonlítjuk össze, melynek során mód nyílik számunkra a csoportok mélyebb megismerésére, alcsoportok azonosítására, valamint különleges kezelésre (felzárkóztatás, tehetséggondozás, motiváció növelés) alkalmas csoport- tagok, alcsoportok kiválasztására. A csoportok teljesítménye alapján felrajzolható a csoportok Lorentz- görbéje [20] is (életgörbe), melynek szintén vizsgálható a deriváltja (diszperziós görbe), valamint integrálja (Gauss- féle hibafüggvény, error function, erf). Ezeknek a görbéknek a paraméterei, lefutása szintén sok összehasonlítási, megismerési szempontot ad a további vizsgálatokhoz. A vizsgálatok során természetesen mindig messzemenően tiszteletben tartjuk a vizsgált csoportokat alkotó hallgatók személyiségi jogait, csak a számszerü eredményeket vizsgáljuk és hasonlítjuk össze. helyezzük el. A jelen cikkben említett görbék Excel-ben történő közelítésére több példát is találhatunk Kehl és Sipos (2009) tanulmányában [21].

\section{A szigmoid görbék létrehozása}

A csoportok szigmoid görbéjének (növekedési görbe) felvételéhez a csoport összes tagjának számszerü eredményét (tesztírás esetén az elért pontszámot) nagyság szerinti sorrendbe rendezzük. Esetünkben az A csoport 10 föt, a B csoport 20 föt tartalmazott.

\section{A csoport:}

2,3,3,7,7,8,11,15,16,20. A pontszámok átlagértéke a csoportban: 9,2 .

\section{B csoport:}

3,3,4,5,6,11,12,16,18,21,21,22,23,25,26,28,28,30,32,33. Átlagérték: 18,35 . A B csoport átlagértéke jelentősen jobbnak mutatkozik, bár el kell mondani, hogy mindkét csoport átlagos pontszámértéke elégtelen osztályzatot eredményez. A két csoport valóságos növekedési görbéje az 1. ábrán látható.

A görbék egyenleteinek felírásához az approximációs eljárás elvégzése szükséges. Esetünkben ezt a már említett Nelder- Mead optimumkereső eljárással végezzük, melynek során a célfüggvény az eltérések összege,melynek lehetséges minimális értékét keressük, a változók a $K, b, r$ értékek. Ahhoz, hogy meghatározhassuk a regresszós együtthatókat, szükséges a Fisher- Pry transzformáció elvégzése is. A csoportok növekedési görbéinek közelítéséhez a következő két növekedési görbét használjuk:

Pearl- Reed : $y=\frac{K}{1+c e^{-r x}}$, és Bertalanffy: $y=K\left(1-c e^{-r x}\right)$. A görbék egyenletében lévő paraméterek értékeit az elérhető legkisebb eltérések esetére az 1. táblázat tartalmazza. 

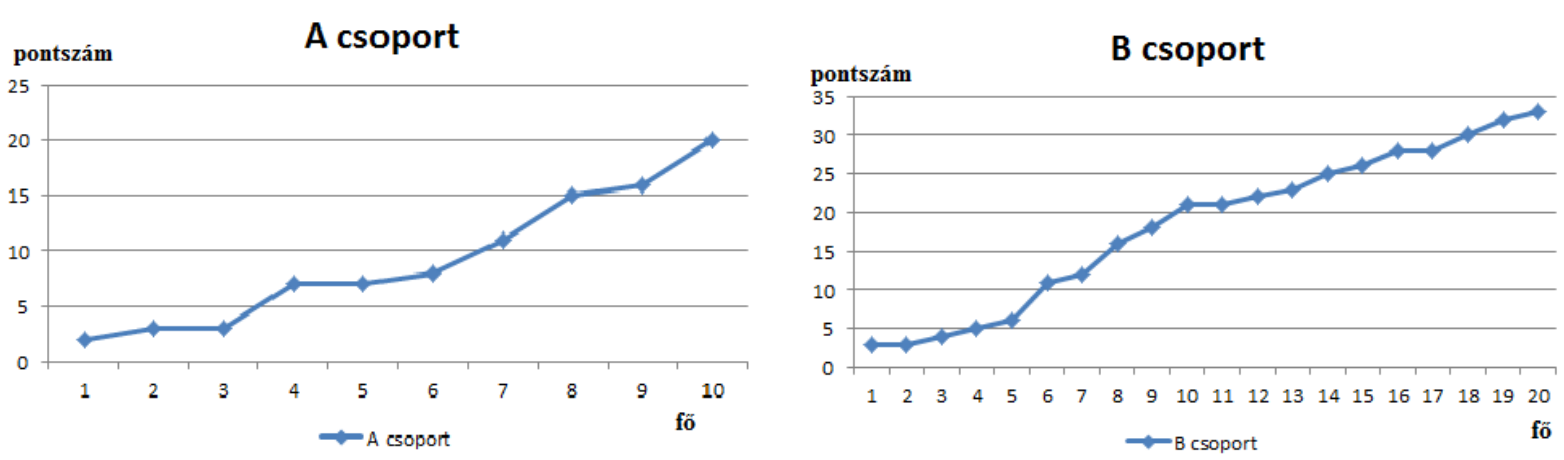

1.ábra. A két csoport eredményei által leirt, valóságos görbék.

1. táblázat. A közelitő függvényekben szereplö paraméterek

\begin{tabular}{|c|c|c|c|c|c|}
\hline & & $K$ & $r$ & $c$ & $\begin{array}{c}\text { regressziós } \\
\text { tényező }\end{array}$ \\
\hline \multirow{2}{*}{$\begin{array}{c}\text { A } \\
\text { csoport }\end{array}$} & Pearl-Reed & 25,53 & 0,373 & 17,08 & 0,98536 \\
\hline & Bertalanffy & 22,22 & 0,0736 & 0,91 & 0,98309 \\
\hline $\begin{array}{c}\text { B } \\
\text { csoport }\end{array}$ & Pearl-Reed & 28,95 & 0,413 & 24,963 & 0,98626 \\
\cline { 2 - 6 } & Bertalanffy & 37,66 & 0,102 & 1,302 & 0,95513 \\
\hline
\end{tabular}

Az 1. táblázat értékeiből jól látszik, hogy a regressziós koefficiens mind az A, mind pedig a B csoport esetében a Pearl- Reed görbe esetén van közelebb 1-hez, tehát a csoportok növekedési függvénye a logisztikai függvényhez van közelebb. A 2. ábra a valóságos görbéket és mindkét közelítő görbét együtt ábrázolja, ezzel szabad szemmel is ellenőrizhetővé válik a közelítés minősége. A további vizsgálatokhoz a csoportok logisztikai görbéjét alkalmazzuk, a jobb regressziós tényezője miatt.

\section{B Csoport}
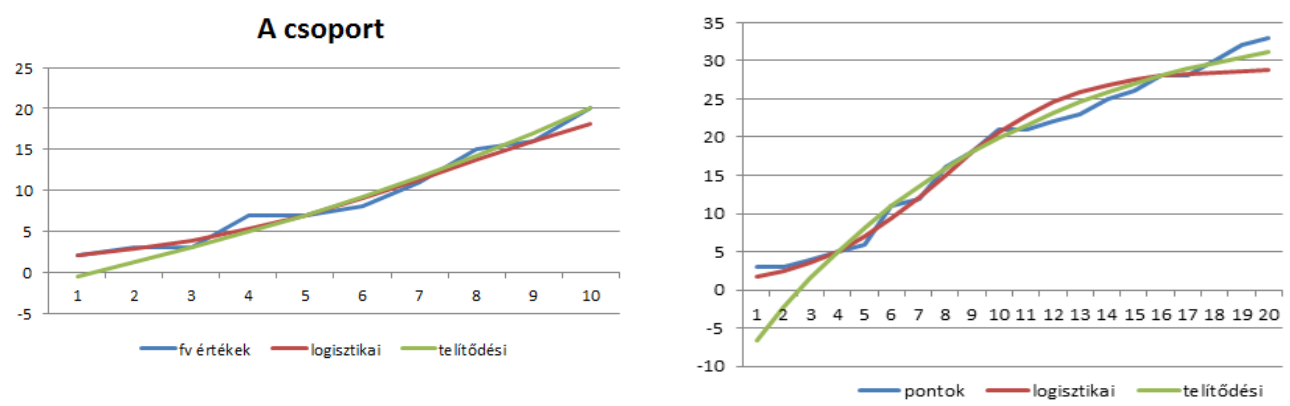

2.ábra. A valóságos és közelitö görbék együtt ábrázolva

A 2. ábra mutatja, hogy a közelítő görbék nagyon közel haladnak a valóságos görbékhez, tehát a közelítés minősége megfelelően jónak tekinthető. Az is kijelenthetö, hogy minél nagyobb a vizsgált csoport létszáma, annál teljesebb logisztikai függvényt mutat a fejlődési görbe, valamint a várható legjobb érték is annál jobb. A két csoport létszámában jelentkező különbség ellenére összehasonlítható, hogy a B csoport legjobb pontszámértéke 10 fö esetén 21, míg az A csoport esetén 20, tehát kis 
mértékben a B csoport eredményei ígérkeznek jobbnak. Ezt alátámasztja a pontszámok átlagértéke: A csoport esetén 9,2, a B csoportnál 18,35. A valóságos görbék és a közelítő görbék közti eltérések is jelentőséggel bírnak: a görbék elején, a növekedés kezdetén a kis pontszámot elért csoporttagok vannak, az ő eredményük elégtelennek minősíthető, azaz ők jelenthetik a felzárkóztató különfoglalkozások, különórák célközönségét. A B csoport esetén látszik a 25-30 pont közötti eredmények esetén, hogy a valós görbe meghaladja a logisztikai görbéből adódó értéket, ez az „átlagos” vagy „számítható” eredmények fölötti érték, tehát ezek a hallgatók kiemelkedőnek tekinthetők, őket tehetséggondozás, TDK (tudományos diákkör), esetleg versenyek, vetélkedők célcsoportjának lehet tekinteni. Szintén a B csoportnál, 20 és 25 pont közötti eredmény esetén a valóságos görbe kissé „leül”, alatta van a logisztikai görbéből adódó értékeknek, bár a csoport átlagától ezek jobb eredmények. Ez azt jelenti, hogy ebben az eredmény- intervallumban több hallgató „leragad”, holott kissé jobb eredményre lehetne tőlük számítani. Ennek oka az itt vizsgált esetben valószínüleg az lehet, hogy 20 pont volt az elégséges osztályzat alsó határa, tehát ennek a csoportnak kifejezetten a minimálisan megfelelő eredmény elérése volt a célja (megúszásra, menekülésre törekvők). Ezt a csoportot érdemes lenne valamilyen motiváció növelő foglalkozással fejleszteni, stimulálni, érdeklődésüket a téma iránt még obban felkelteni, mivel valószínủleg jelentősen jobb eredményekre is képesek lennének, ha valamilyen vonzó célt tudnánk eléjük kitüzni, vagy valamilyen módon nagyobb elismerés társulna a jobb eredményhez.

\section{A görbék deriváltjának és integráljának vizsgálata}

A logisztikai görbe deriváltjának egyenlete: $\quad \frac{d y(x)}{d x}=\frac{k c r e^{-r x}}{\left(1+c e^{-r x}\right)^{2}} \quad$, az integrálja a következő módon számolható:

$$
\int y(x) d x=-\frac{K}{r} \ln \left(e^{-r x}\right)+\frac{K}{r} \ln \left(1+c e^{-r x}\right)
$$

A Bertalanffy- görbe deriváltja:

$$
\frac{d y(x)}{d x}=K r c e^{-r x}, \text { integrálja: } \quad \int y(x) d x=K x+\frac{K c}{r} e^{-r x} .
$$

A deriváltak és az integrálok egyenletében szereplő $K, r, c$ paraméterek ugyanazok, mint az 1. táblázatban található értékek. Az A csoport logisztikai görbéjének deriváltja és integrálja a 3. ábrán, a B csoporté a 4. ábrán látható. Az A csoport görbéjét az ábrázolás során 20 föig mutatjuk, ezzel mintegy extrapolálva az eredményeket, így az eredmények jobban összehasonlíthatók a két csoport vizsgálata során.

A görbék összehasonlításakor elmondható, hogy a logisztikai görbe deriváltja és integrálja esetén a két csoport görbéinek lefutása teljesen hasonló, különbségeket a kisebb részletek, számszerü értékek összehasonlításakor találhatunk. A derivált görbéket nézve a görbe két legjellemzőbb tulajdonsága a maximum helye és a maximum értéke, magassága. A maximum helye az A csoport esetén 7,5 értéknél van, a B csoport esetén 7,8-nál, a maximum értéke az A csoportnál 2,38 és a B csoportnál 2,97 . Mivel a görbe deriváltja a növekedés sebességével van összefüggésben, ezért a maximum érték alapján azt mondhatjuk, hogy a B csoport esetén nagyobb a növekedési sebesség. A maximum helye azt mutatja, hogy a maximális növekedéshez hány fő eredményeinek vizsgálatára van szükség. Ez az A csoport esetén kicsit kevesebb, mint a B csoportnál, ezért ebböl a szempontból az A csoport tekinthető egy kicsit jobbnak, hamarébb eléri a maximális értéket a növekedési sebesség. A logisztikai görbe deriváltjának vizsgálatakor hasznos eredményt mutathat a görbe maximumának fele magasságban mérhető 
szélesség értéke. Ez az A csoportnál 7,8 és a B csoport esetén 8,5 értékü. A nagyobb szélesség azt jelzi, hogy több csapattag eredménye van a legnagyobb növekedés környezetében, így ez előnyösebb tulajdonságnak vehető.

A logisztikai görbe integrálját összehasonlítva az tapasztalható, hogy a két csoport integrál- görbéje teljesen hasonló, kis különbség az elért számértékekben van, ami abból ered, hogy a B csoport logisztikai görbéjében a $K$ paraméter értéke nagyobb, mint az A csoportéban, így az integrál értéke is értelemszerüen nagyobb.
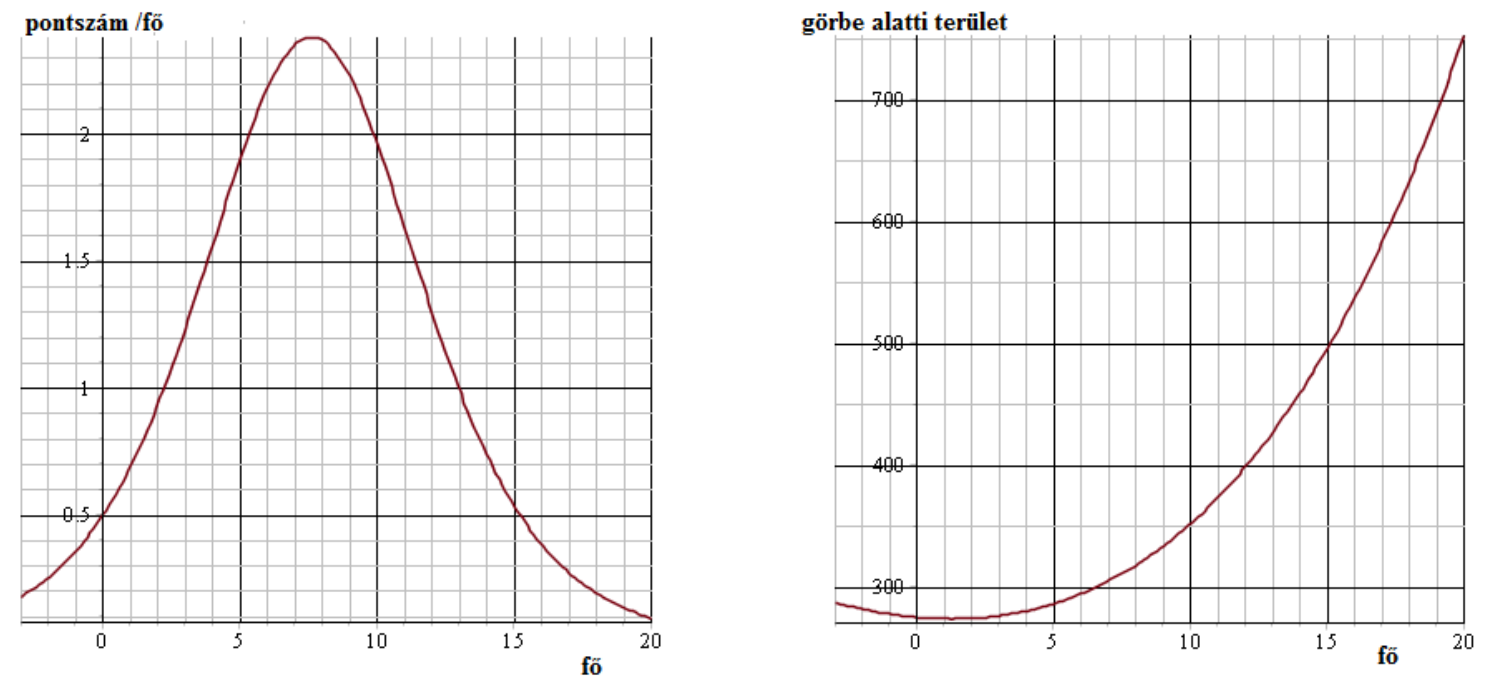

3.ábra. Az A csoport logisztikai görbéjének deriváltja és integrálja
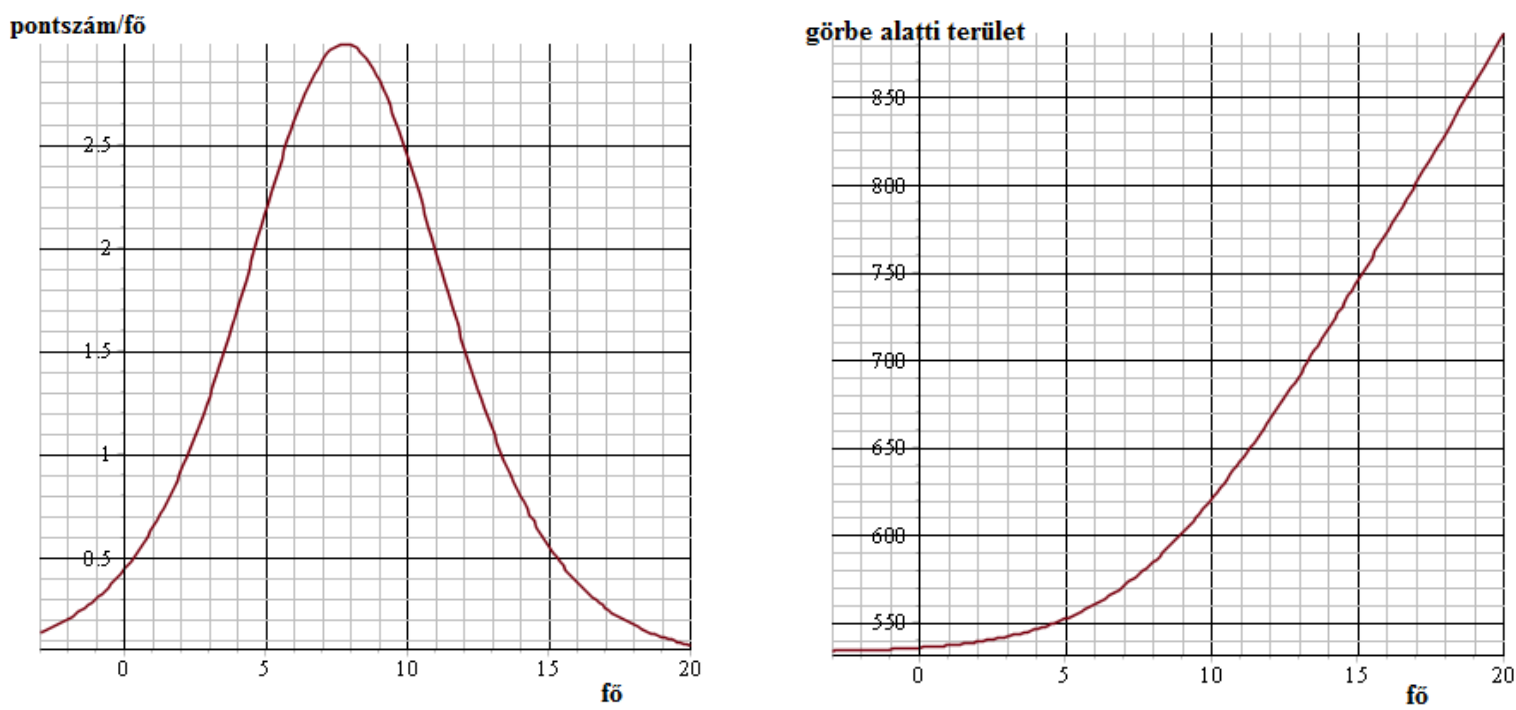

4.ábra. A B csoport logisztikai görbéjének deriváltja és integrálja 


\section{4. Életgörbe, diszperziós görbe, spektrum}

A logisztikai görbe deriváltjának „harangszerü” alakja nagyon hasonló az úgynevezett életgörbéhez, vagy Lorentz görbéhez. Ezt a görbét szintén elő lehet állítani a csoportok eredményei alapján, majd ennek is lehet vizsgálni a deriváltját és az integrálját, amiből szintén hasznos következtetések vonhatók le a csoportok viselkedésére, jellemzőire vonatkozóan.

A görbe előállításához a pont-eredmények alapján a csoporttagoknak osztályzatot kell adni. Ez Magyarországon általában ötfokozatú skála alkalmazásával történik: a maximális elérhető pontszám kb. 40\%-a szükséges az elégséges, azaz 2-es eredményhez, ez alatt elégtelen, azaz 1 -es az eredmény. A többi osztályzathoz (3- közepes, 4- jó, 5- jeles) szükséges pontszám- értékek egyenközü beosztás alapján számíthatók. Ha minden csoporttagnak kialakítottuk az osztályzatát, akkor azt kell megnéznünk, hogy az egyes osztályzatokat hányan érték el a csoportban. Ezt ábrázoljuk, a vízszintes tengelyen az osztályzatokat 1-től 5-ig feltüntetve, a függőleges tengelyen pedig a létszámot, hogy hányan érték el.

Az így kialakuló görbe a csoport „spektruma”, életgörbéje. Nagyon erős a hasonlóság a csoport életgörbéje és egy rezgő rendszer spektruma között, mivel az életgörbénél is bizonyos értékeknél „amplitudó" növekedést tapasztalhatunk, hasonlóan a sajátfrekvencia értékek közelében a rezgő rendszernél. Tehát mondható, hogy a dolgozat úgy hatott a csoportra, mint a gerjesztés a rezgő rendszerre, és kiadódtak a csoport sajátértékei. Az is fontos összehasonlítási szempont lehet, hogy egy csoportnak hány darab sajátértéke van, mely osztályzatoknál vannak ezek a sajátértékek, és milyen az életgörbe alakja a sajátérték környezetében, azaz milyen magas ,amplitudó” alakul ki, illetve a maximális amplitudó fele magasságában milyen a görbe jellemző szélessége. Az A csoport esetében két sajátértéket találtunk, a B csoport esetében hármat, a harmadik sajátérték magasabb osztályzatnál helyezkedik el, mint az A csoport legmagasabb sajátértéke. Az amplitudó magassága annál jobb jellemzőt jelent a csoport számára, minél magasabb osztályzatnál van, a görbe szélessége pedig az adott sajátérték tömegbázisával, jelentőségével van kapcsolatban (szignifikancia). Ennek az értéknek is akkor jó a nagyobb kiterjedése, ha a hozzá tartozó sajátérték (osztályzat) minél jobb.

Az A csoport életgörbéje az 5. ábrán látható, az ábra felső részében kékkel a teljes spektrumot mutatva, de mindegyik sajátértéknél külön- külön közelítő életgörbét megadva, majd ezeket a görbéket egy tengelykeresztben egyszerre ábrázolva. A B csoport sajátértékeit hasonló kialakításban a 6 . ábra mutatja. Az életgörbének is képezhető a deriváltja (ezt nevezzük diszperziós függvénynek), valamint integrálja (ez az úgynevezett hibafüggvény, error function, ,erf”, ez lesz szigmoid alakú), mindegyik sajátértékhez tartozóan. Ezek láthatók az A csoport esetén a 7. ábrán, a B csoportra pedig a 8. ábrán. Mivel az életgörbe integrálja szigmoid jellegü függvény, ennek az egyenletében szereplő $K, r, c$ értékek értelmezése, összehasonlítása teljesen hasonlóképpen történhet, mint ahogy azt a logisztikai függvény esetében tettük. Az életgörbe deriváltját, azaz a diszperziós függvényt gyakran alkalmazzák a részecskefizikában. Az ottani következtetések, gondolatok megfelelő értelmezése, „transzformációja” további hasznos jellemzők megismerését teheti lehetővé a jövőben, a csoportokat alkotó egyének eredményeire vonatkozóan. 

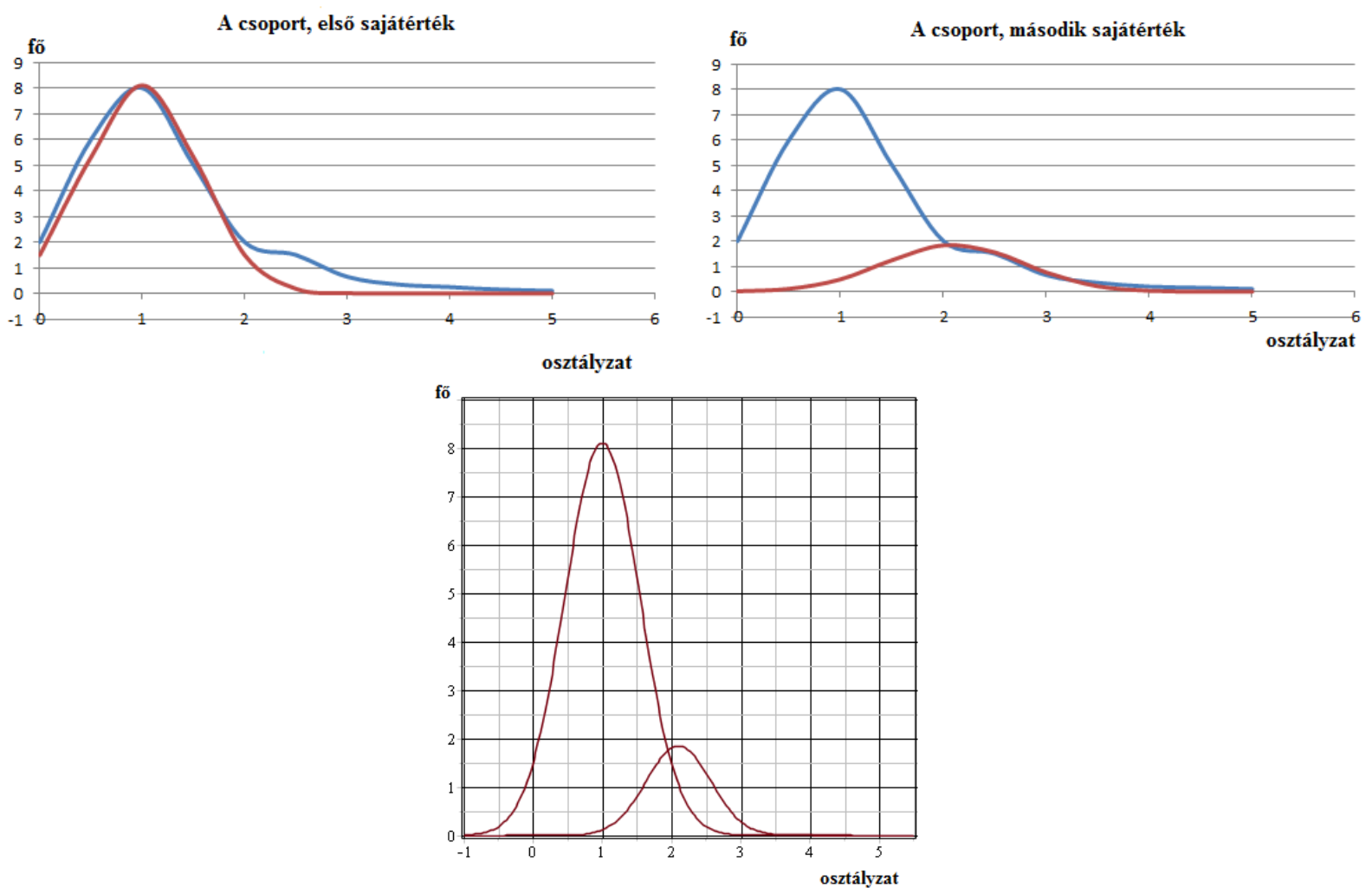

5.ábra. Az A csoport életgörbéje

Az életgörbe egyenlete, deriváltja, integrálja a következő alakú:

az életgörbe egyenlete: $y(x)=\frac{K}{e^{c^{2}(x-r)^{2}}}$, első derivált: $\frac{d y(x)}{d x}=-\frac{K\left(2 c^{2} x-2 c^{2} r\right)}{e^{c^{2}(x-r)^{2}}}$,

integrál:

$$
\int y(x) d x=\frac{K \sqrt{\pi}}{2 c} \operatorname{erf}(c(x-r)), \quad \operatorname{erf}(x)=\frac{2}{\sqrt{\pi}} \int_{0}^{x} e^{-t^{2}} d t
$$

erf(x) az úgynevezett Gauss-féle error function [22], (Andrews 1998). A (9)- (10) egyenletekben szereplő $K, r, c$ paraméterek értékei a csoportok sajátértékeire vonatkozóan a 2. táblázatban láthatók. 

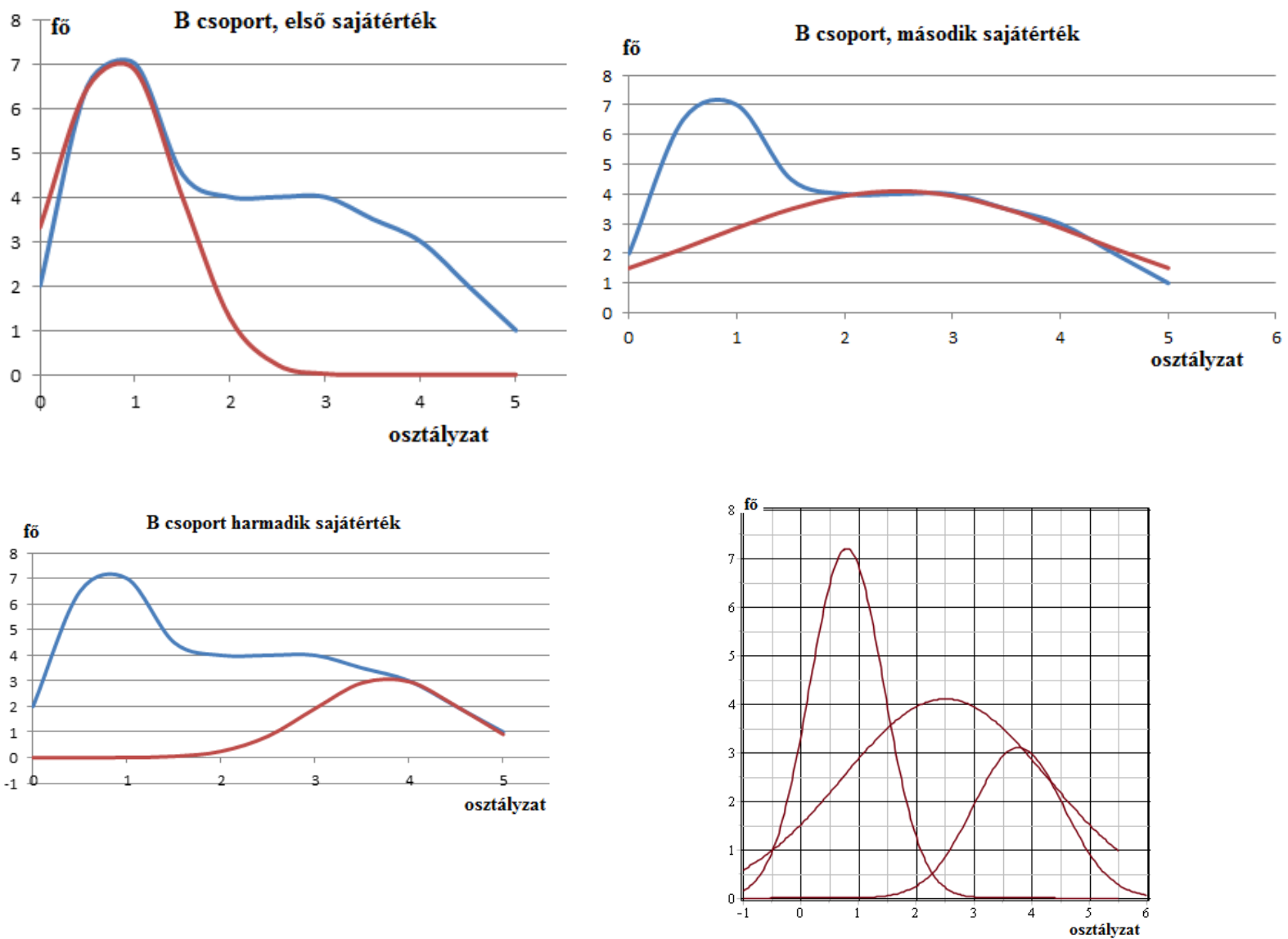

6.ábra. A B csoport életgörbéje

2. táblázat. Az életgörbe-egyenletek paraméterei

\begin{tabular}{|c|c|c|c|}
\hline & $K$ & $r$ & $c$ \\
\hline $\begin{array}{c}\text { A csoport, első } \\
\text { sajátérték }\end{array}$ & 8,1 & 1,0 & 1,3 \\
\hline $\begin{array}{c}\text { A csoport, máso- } \\
\text { dik sajátérték }\end{array}$ & 1,85 & 2,1 & 1,05 \\
\hline $\begin{array}{c}\text { B csoport, első } \\
\text { sajátérték }\end{array}$ & 7,2 & 0,8 & 1,1 \\
\hline $\begin{array}{c}\text { B csoport, máso- } \\
\text { dik sajátérték }\end{array}$ & 4,1 & 2,5 & 0,4 \\
\hline $\begin{array}{c}\text { B csoport, harma- } \\
\text { dik sajátérték }\end{array}$ & 3,1 & 3,77 & 0,9 \\
\hline
\end{tabular}



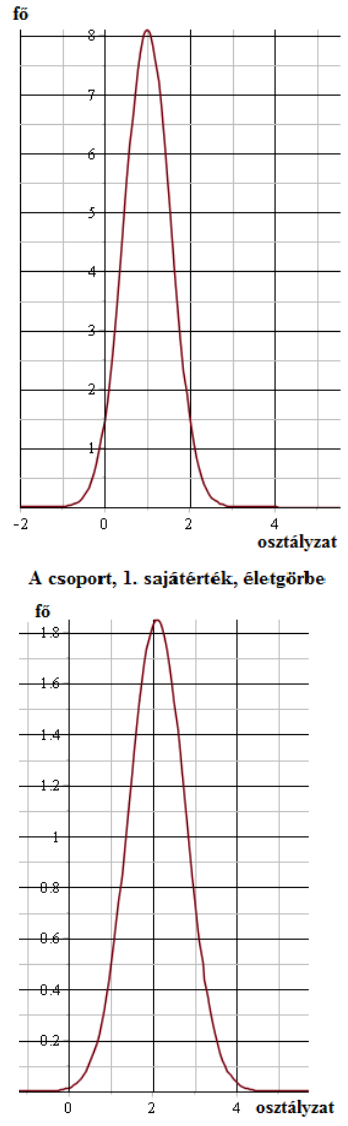

A csoport, 2. sajátérték, életgörbe

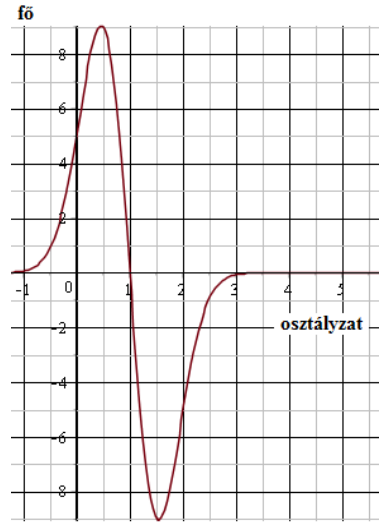

A 1 derivált

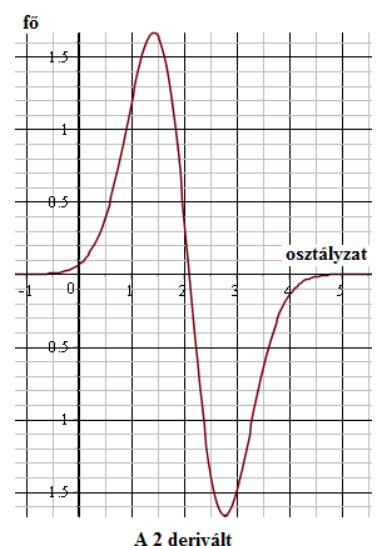

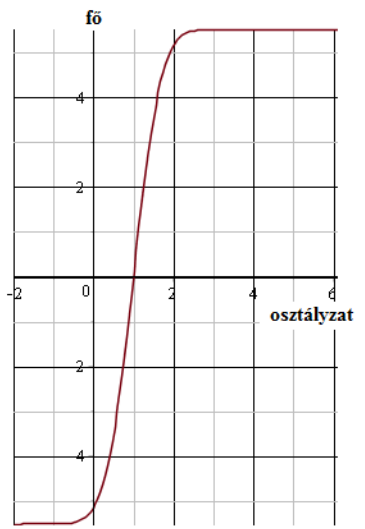

A 1 integrál

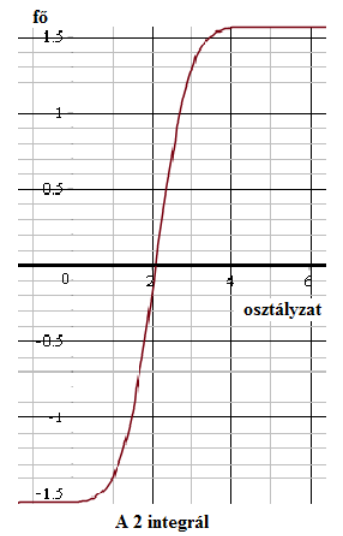

7.ábra. Az A csoport életgörbéjének deriváltja, integrálja

A sajátértékekhez tartozó életgörbék összehasonlításakor látható, hogy az első sajátérték mindkét csoportnál az 1 (elégtelen) osztályzatnál van, tehát sajnos elmondható, hogy több hallgató ért el mindkét csoportban elégtelen eredményt, azaz az elégtelen mindkét csoportban „sajátérték”. Különbség az elégtelen sajátértéknél tapasztalható „amplitudó” értékében mutatkozik, hiszen az A csoportnál az amplitudó értéke 8,1 a B csoportnál pedig 7,2 tehát kevesebb hallgató ért el a B csoportban elégtelen eredményt, mint az A csoportban. Az életgörbe fél amplitudó magasságban mérhető szélességét tekintve az A csoportnál ez a távolság 1,26 osztályzatnyi távolságot jelent, míg a B csoportnál ez 1,75 osztályzatnyi távolságot tesz ki. Ez azt jelenti, hogy a B csoportban „súlyosabb” ez a sajátérték, mint az A csoportban. Mivel ez a sajátérték az elégtelen eredményhez tartozik, azaz nem tekinthető sikeres, büszkélkedni való eredménynek, ezért a kisebb szignifikancia jobb, ezért ebből a szempontból az „A csoporté a pont", ezt a szempontot ez a csoport nyeri meg. A második és harmadik sajátérték esetén azonban a B csoporté a pont, mivel a sikeres eredményeknél a nagyobb szignifikancia érték a jobb.

A második sajátérték tekintetében az A csoportnál a 2,2 osztályzatnál lép ez fel, a B csoportnál 2,4nél van, tehát a B csoporté magasabb. A szignifikancia szélesség az A csoportnál 1,44 osztályzatnyi távolságnak fele meg, a B csoportnál ez az érték 4,125 osztályzatnyi, azaz lényegesen szignifikánsabb. 
Mivel ez a sajátérték a 2 azaz elégséges szintet meghaladja, a szignifikánsabb sajátérték a B csoportnál azt jelenti, hogy lényegesen jellemzőbb az elégséges osztályzat a csoportban, mint az A csoport esetében. Az elégséges osztályzat sikeresebbnek tekinthető, mint az elégtelen, így ebben az esetben a nagyobb szignifikancia ennél a sajátértéknél a B csoport javára dönti el a szempont megnyerését.
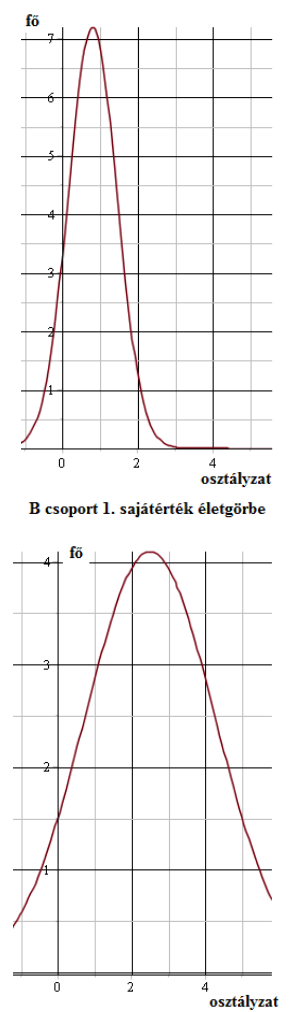

B csoport 2. sajátérték életgörbe

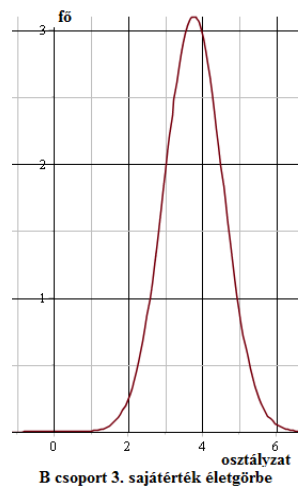

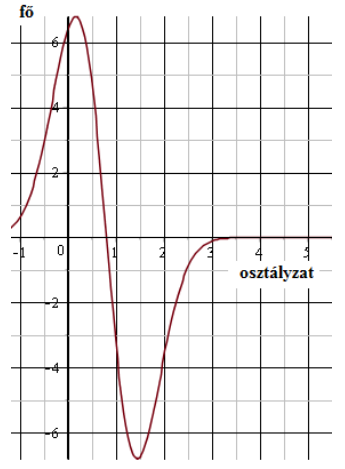

B 1 derivált

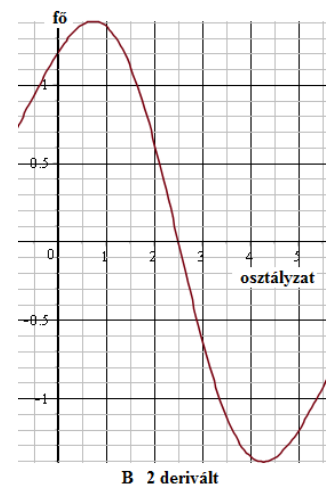

B 2 derivalt

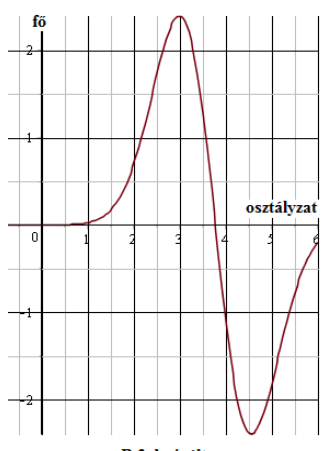

B 3 derivált

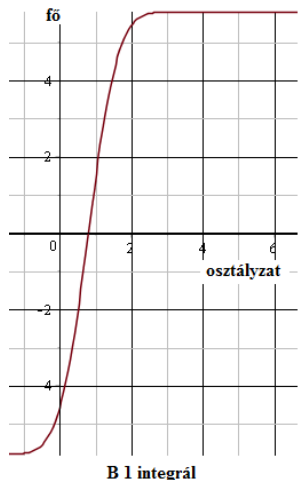

B 1 integrál

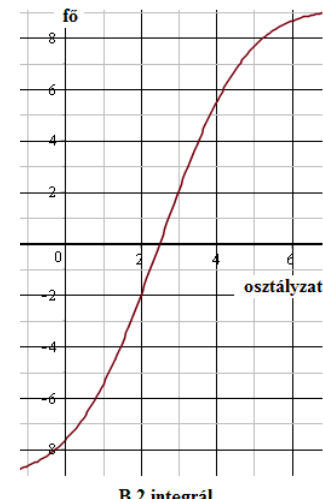

B 2 integrál

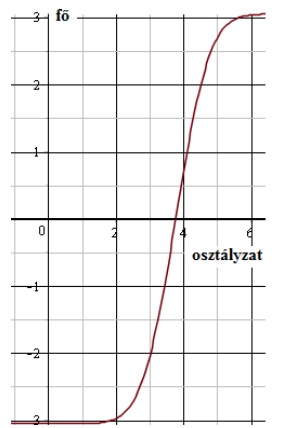

B 3 integrál

8.ábra. A B csoport életgörbéjének deriváltja, integrálja

A harmadik sajátérték létezése pedig a B csoportnál tiszta nyereséget jelent, hiszen az A csoportnál sajnos ilyen magas osztályzatú sajátérték nincs, tehát ilyen eredményt senki sem ért el abban a cso- 
portban, viszont a B csoportban ennek a jó eredménynek a szignifikanciája 1,75 értékü, tehát nem jelentéktelen. Ez alapján a harmadik sajátérték összehasonlítását teljes mértékben a B csoport nyeri.

Az életgörbe deriváltjait összehasonlítva a legszembetünőbb a diszperziós függvény zérushelye, ez minél magasabb osztályzatnál van, annál jobb. Az első sajátérték esetén az A csoportnál ez az érték 1,0 a B csoportnál 0,9 tehát ebben az esetben az A csoport nyer, a második sajátértéknél az A csoport 2,1 a B csoport pedig 2,5 értékkel rendelkezik, tehát ezt a szempontot a B csoport nyeri. A harmadik sajátértéknél a B csoport 3,8 értéke ellenfél nélkül nyer, mert az A csoportnál nincs ilyen érték.

Az életgörbe integrálja (hibafüggvény) és ennek jellemzői nehezebben értelmezhető szempontokat adnak, de az mindenképpen elmondható, hogy a görbe zérushelye akkor jobb, ha magasabb osztályzatnál van, ez alapján az első sajátértékhez tartozó hibafüggvény összehasonlítását az A csoport nyeri, a másodikat a B csoport, és a harmadik sajátértéknél szintén a B csoport nyer. Az integrál függvény $K$ értéke akkor jobb, ha kisebb értékű, mert akkor kevesebb hallgató szükséges az adott eredményhez. Az összes eddig vizsgált és ismertetett görbe lefutásából, valamint a bennük szereplő paraméterek számértékéből alkotható szempontokat egy összefoglaló táblázatba (3. táblázat) foglaltuk össze. Mindegyik szempont esetén feltüntettük, hogy az adott szempontot melyik csoport nyeri meg. A szempontok eredményeinek összesítéséből kialakítható az összpontszám, ami a két csoport összesített eredményét mutatja. A táblázatban több, mint 30 szempontot gyüjtöttünk össze.

\section{5. Összefoglalás}

Jelen munkában két hallgatói csoport teljesítményét hasonlítjuk össze, akik ugyanazt a zárthelyi feladatsort írták meg a Gépészmérnöki alapismeretek címü tárgy keretében. Az összehasonlításra az EBSYQ módszert alkalmaztuk, mely a csoportok jellemző görbéit képezi, melyek növekedési illetve logisztikai görbék lehetnek, majd ezeknek a szigmoid görbéknek az egyenletében szereplő paraméterek és a görbék lefutásának, alakjának sajátosságai alapján több szempontot tartalmazó összehasonlítási rendszert tartalmaz. A vizsgálatok és az összehasonlítások azt mutatják, hogy a csoportok jellemző görbéit a Pearl- Reed féle logisztikai függvény közelíti jobban. Ezt támasztja alá a regressziós koefficiensek értékeinek összehasonlítása is, ez az érték a Pearl-Reed féle logisztikai függvény esetén jobb. Ez azt is jelenti, hogy a hallgatói csoportok egy zárthelyi dolgozatra képződő eredményeinek viselkedése a logisztikai függvénynek megfelelően alakul. A görbék egyenletében szereplő $K$ érték a csoport által elérhető legjobb eredményt jelenti, az $r$ paraméter a növekedési sebességgel kapcsolatos, a $c$ paraméter a görbe horizontális elhelyezését mutatja. A görbéknek képezhető a deriváltja és az integrálja is, melyek még további szempontokat adnak az összehasonlításra. Ez az összehasonlítási rendszer akkor lehet nagyon hasznos, ha nemcsak egy gyors, összevetés szerü, egy pillantás alatt elvégezhető, felületes véleményalkotásra van szükség, hanem komolyan, mélyen kívánjuk a csoportok teljesítményét, a bennük rejlö alcsoportokat, egyéneket megismerni, és esetleg az egyes alcsoportokra „testre" szabottan különórákat, foglalkozásokat, irányított tevékenységeket is tervezünk végezni (pl. felzárkóztató foglalkozás, motivációs tréning, tehetséggondozás, stb.). A görbék paramétereinek összehasonlítása nagyon éles, tüpontos, jól számszerüsíthető, maximálisan objektív és részletes képalkotást tesz lehetővé a csoportok teljesítményét ezzel a módszerrel vizsgáló szakértő (felkészítő tanár, szakfelügyelő, ellenőr, bíráló) számára. Különösen hasznos lehet ez a módszer, ha versenyek, támogatás odaítélések, állásinterjúk esetén több, egymáshoz nagyon közel álló teljesítményü személyt kell összehasonlítani és csak nagyon finom, nüansznyi eltérések vannak, amik esetleg ki is egyenlítik egymást, azaz az egyik jelentkező ebben jobb, a másik abban, stb. A módszer az ilyen esetekben tud a legjobban segítségére lenni a „nehéz helyzetben” lévő zsürinek a pontos, jól alátámasztható és sok részletet látványosan ki- 
domborító jellemzések megalkotásában és a garantáltan objektív, számszerüen alátámasztható fontos döntés meghozatalában. Az összehasonlítási folyamat végeredménye könnyen összegezhető. Ezt jelentheti a megnyert szempontok számának összesítése, vagy lehetséges az is, hogy az így nyert eredményt olyan, különböző sportok eredmény- számaival interpretáljuk, ami hozzájárul a kialakuló végeredmény még gyorsabb és egyszerübb értelmezéséhez, és ez alapján a végső döntés meghozatalához, a végső nyertes eldöntéséhez. A bemutatott szempontok arra is alkalmasak, hogy a vesztes csoport által megnyert pontokat, illetve a nyertes csapatéhoz közeli eseteket összegyüjtve, számszerüen alátámasztható adatok alapján vigasztaló, motiváló, a jó oldalt és az elért eredményeket kiemelő szavakat, gondolatokat tolmácsolhassunk, így nem csak „üres” vigasztalás lesz, hanem tényszerü, számadatokkal jobban alátámasztott biztatás. A cikkben bemutatott módszer alapján a csoportok teljesítményéről kinyerhető információk nagyon hasznosak lehetnek a minőségbiztosítási szakemberek számára is, szempontokat adva az adott tevékenység jelenlegi hatékonyságának felméréséhez, jellemzéséhez és az esetleges javítási, beavatkozási pontok beazonosításához, kijelöléséhez. A részletes számszerủ eredmények pedig a beavatkozás után annak hatásosságát, eredményességét is jól, részletesen, számszerü eredményekkel tudja kimutatni. A módszer egyetlen hátránya az időigényesség, mivel a görbék felvétele, approximációja, deriváltjaiknak, integráljuknak a képzése és az eredmények részletes összehasonlítása időt vesz igénybe (néhány munkaóra). Az életgörbe, a diszperziós görbe és a Gauss-féle hibafüggvény további analíziséböl, a levonható következtetéseknek a csoportokra, valamint az azokat alkotó alcsoportokra, egyénekre történő még részletesebb értelmezéséből még további hasznos szempontok lesznek képezhetőek a jövőbeni továbbfejlesztés során.

\section{Köszönetnyilvánítás}

A cikkben ismertetett kutató munka az EFOP-3.6.1-16-2016-00011 jelü „Fiatalodó és Megújuló Egyetem - Innovatív Tudásváros - a Miskolci Egyetem intelligens szakosodást szolgáló intézményi fejlesztése" projekt részeként - a Széchenyi 2020 keretében - az Európai Unió támogatásával, az Európai Szociális Alap társfinanszírozásával valósul meg.

\section{Irodalom}

[1] Malthus,T.: An Essay on the Principle of Population. Printed for J. Johnson in St Paul's ChurchYard, London, 1798.

[2] Moore, E. G.: Cramming more components onto integrated circuits. Electronic Magazine 1965, 38(8):114- 117. https://doi.org/10.2307/2688444

[3] Verhulst, P.-F.: Deuxieme mémoire sur la loi d'accroissement de la population. Mémoires de l'Académie Royale des Sciences, des Lettres et des Beaux- Arts de Belgique 1847, 20:1-32. Retrieved 18 February 2013.

[4] Pearl, R.; Reed, L. J.: On the rate of growth of the population of the United States since 1790 and its mathematical representation. Proceedings of the National Academy of Sciences 1920, 6(6):275-288. https://doi.org/10.1073/pnas.6.6.275

[5] Fisher, J. C., Pry, R. H.: A simple substitution model of technological change. Technological forecasting and social change 1971, 3:75-88. https://doi.org/10.1016/S0040-1625(71)80005-7

[6] Bertalanffy, L.: Principles of theory of growth. In: Fundamental Aspects of Normal and Malignaent Growth. Amsterdam. pp. 137-259, 1960. 
[7] Kozuko, F., Bajzer, Z.: Combining Gompertzian growth and cell population dynamics. Mathematical Biosciences 2003, 185:153- 167. https://doi.org/10.1016/S0025-5564(03)000944

[8] Richards, F. J.: A flexible growth function for empirical use. Journal of Experimental Botany 1959, 10:290-300. http://dx.doi.org/10.1093/jxb/10.2.290

[9] Mansfield, E.: Technical change and the rate of imitation. Econometrica 1961, 29(4):741- 766. https://doi.org/10.2307/1911817

[10] Rogers, M. E.: Diffusion of innovations. (Third edition). The Free Press, Macmillan Publishing Co. Inc., New York, USA. p. 236. 1962.

[11] Jang, S.L., Dai, S. C., Sung, S.: The pattern and externality effect of diffusion of mobile telecommunications: the case of OECD and Taiwan. Information Economics and Policy 2005, 17:133-148. https://doi.org/10.1016/j.infoecopol.2004.05.001

[12] Meyer, W. B., Turner, B. L.: Changes in land use and land cover: a global perspective. Cambridge University Press, 1994. ISBN 0521470854.

[13] Silverberg, G., Lehnert, D.: Evolúciós káosz: növekedés és fluktuációk az „alkotó rombolás” Schumpeter- féle modelljében. In: Fokasz Nikosz (szerk.): Káosz és nemlineáris dinamika a társadalomtudományokban. Typotex kiadó, 2003.

[14] Nikosz, F.: Növekedési görbék, társadalmi diffúzió, társadalmi változás. http://www.socialnetwork.hu/cikkek/FokaszDiffuzio.pdf Legutóbbi felkeresés: 2019. nov. 22.

[15] Szabó, F. J.: Analógia a sport- világcsúcsok története és az evolúciós optimáló algoritmusok iteráció- története között. GÉP 2011, 62(9-10):28-31.

[16] Szabó, F. J.: Optimumkereső algoritmusok iterációtörténetének vizsgálata. GÉP 2018, 69(4):8285.

[17] Szabó, F. J.: Application of sigmoid curves in environmental protection. In: Szita Tóthné, Klára, Jármai Károly, Voith Katalin (szerk.): Solutions for Sustainable Development: Proceedings of the 1st International Conference on Engineering Solutions for Sustainable Development, (ICESSD 2019). London, Egyesült Királyság / Anglia: CRC Press, pp. 1-7, 2019.

[18] Nelder, J. A., Mead, R.: A simple method for function minimisation. Computer Journal 1965, 7:308- 313. https://doi.org/10.1093/comjnl/7.4.308

[19] Lorentz, M. O.: Methods of measuring the concentration of wealth. Publications of the American Statistical Association 1905, 9(70):209-219. https://doi.org/10.2307/2276207

[20] Kehl, D.; Sipos, B.: A telítődési, a logisztikus és az életgörbe becslése Excel parancsfájl segítségével. Statisztikai Szemle 2009, 87(4):381-411.

[21] Andrews, L. C.: Special functions of mathematics for engineers: SPIE Optical Engineering Press: Bellingham, USA, 1998. 


\section{Melléklet}

3. táblázat. Az eredmények összefoglaló táblázata

\begin{tabular}{|c|c|c|c|c|c|c|}
\hline $\begin{array}{c}\text { A görbe } \\
\text { típusa }\end{array}$ & Paraméter neve & Jelölés & $\begin{array}{l}\text { Szán } \\
\text { A csop. }\end{array}$ & $\begin{array}{l}\text { rték } \\
\text { B csop. }\end{array}$ & Megjegyzés & $\begin{array}{l}\text { Nyertes } \\
\text { csoport }\end{array}$ \\
\hline \multirow{3}{*}{$\begin{array}{l}\text { Valóságos } \\
\text { eredmény- } \\
\text { görbe }\end{array}$} & Csoportlétszám & $\mathrm{n}$ & 10 & 20 & $\begin{array}{l}\text { Akik a dolgozatot } \\
\text { megírták }\end{array}$ & - \\
\hline & Átlagos pontérték & átl. pt. & 9,2 & 18,35 & $\begin{array}{c}\text { Könnyen } \\
\text { összehasonlítható }\end{array}$ & $\mathrm{B}$ \\
\hline & Átlagos osztályzat & $\mathrm{P}_{\mathrm{av}}$ & 1 & 1 & $\begin{array}{c}\text { Gyorsan } \\
\text { összehasonlítható }\end{array}$ & - \\
\hline \multirow{4}{*}{$\begin{array}{l}\text { Bertlanffy- } \\
\text { görbe } \\
\text { (növekedési) }\end{array}$} & Regressziós koefficiens & $\mathrm{R}_{\mathrm{kg}}$ & 0,983 & 0,986 & Korreláció erőssége & $\mathrm{B}$ \\
\hline & $K$ & $K$ & 22,22 & 37,66 & $\begin{array}{c}\text { A csoport maximális } \\
\text { eredménye }\end{array}$ & $\mathrm{B}$ \\
\hline & $r$ & $r$ & 0,07 & 0,102 & $\begin{array}{l}\text { Fejlődési (növekedé- } \\
\text { si) sebesség }\end{array}$ & $\mathrm{B}$ \\
\hline & $c$ & $c$ & 0,91 & 1,302 & $\begin{array}{l}\text { Vegyes hatású } \\
\text { paraméter }\end{array}$ & - \\
\hline \multirow{11}{*}{$\begin{array}{l}\text { Pearl- Reed } \\
\text { görbe } \\
\text { (logisztikai) }\end{array}$} & Regressziós koefficiens & $\mathrm{R}_{\mathrm{kl}}$ & 0,985 & 0,986 & Korreláció erőssége & $\mathrm{B}$ \\
\hline & Elégtelenek száma & $\mathrm{A}_{\mathrm{m}}$ & 8 & 7 & Alulmotiváltság & $\mathrm{B}$ \\
\hline & $K$ & $K$ & 25,53 & 28,95 & $\begin{array}{c}\text { A csoport maximális } \\
\text { eredménye }\end{array}$ & B \\
\hline & $r$ & $r$ & 0,373 & 0,413 & Növekedési sebesség & $\mathrm{B}$ \\
\hline & $c$ & $c$ & 17,08 & 24,963 & $\begin{array}{c}\text { Vegyes hatású } \\
\text { paraméter }\end{array}$ & - \\
\hline & Alul- motiváltság helye & $\mathrm{M}_{\mathrm{h}}$ & 8 & 20 & Pontérték & $\mathrm{B}$ \\
\hline & Alul- motiváltak száma & $\mathrm{M}_{\mathrm{sz}}$ & 3 & 5 & Alcsoport & A \\
\hline & Kiváló eredmény (pont) & $\mathrm{U}$ & 20 & 33 & $\begin{array}{c}\text { Legjobb eredmény, } \\
\text { rekord }\end{array}$ & $\mathrm{B}$ \\
\hline & Kiváló hallgatók száma & $\mathrm{U}_{\mathrm{sz}}$ & 2 & 3 & $\begin{array}{l}\text { A legjobb alcsoport } \\
\text { létszáma }\end{array}$ & $\mathrm{B}$ \\
\hline & Jó motiváltság helye & $\mathrm{E}_{\mathrm{m}}$ & 20 & 30 & $\begin{array}{l}\text { Milyen pon- } \\
\text { teredménynél }\end{array}$ & $\mathrm{B}$ \\
\hline & Jól motiváltak száma & $\mathrm{E}_{\mathrm{sz}}$ & 2 & 3 & Hallgatók létszáma & $\mathrm{B}$ \\
\hline \multirow{2}{*}{$\begin{array}{l}\text { Logisztikai } \\
\text { görbe deriv. }\end{array}$} & Maximális növ. sebesség & $\mathrm{V}_{\mathrm{fmax}}$ & 2,4 & 3,0 & Magas motiváltság & $\mathrm{B}$ \\
\hline & Maximum helye & $\mathrm{V}_{\mathrm{m}}$ & 7,5 & 7,8 & Milyen eredménynél & $\mathrm{B}$ \\
\hline \multirow{10}{*}{$\begin{array}{l}\text { Életgörbe } \\
\text { (Lorentz- } \\
\text { függvény) }\end{array}$} & $K$ & $K$ & 1,85 & 4,1 & $\begin{array}{c}\text { A legjelentősebb } \\
\text { sajátértéknél }\end{array}$ & $\mathrm{B}$ \\
\hline & $r$ & $r$ & 2,1 & 2,5 & Szóródás & - \\
\hline & $c$ & $c$ & 1,05 & 0,4 & $\begin{array}{l}\text { Vegyes hatású } \\
\text { paraméter }\end{array}$ & A \\
\hline & Sajátértékek darabszáma & $\mathrm{S}$ & 2 & 3 & $\begin{array}{c}\text { Hány alcsoport } \\
\text { azonosítható }\end{array}$ & $\mathrm{B}$ \\
\hline & Sajátérték $1\left(\mathrm{~s}_{1}\right)$ & $\mathrm{s}_{1}$ & 1,0 & 1,0 & $\begin{array}{c}\text { Sajátérték, alcsoport } \\
1\end{array}$ & - \\
\hline & Sajátérték $2\left(\mathrm{~s}_{2}\right)$ & $\mathrm{s}_{2}$ & 2,2 & 2,5 & $\begin{array}{c}\text { Sajátérték, alcsoport } \\
2\end{array}$ & $\mathrm{~B}$ \\
\hline & Sajátérték $3\left(s_{3}\right)$ & $\mathrm{s}_{3}$ & - & 3,8 & $\begin{array}{c}\text { Sajátérték, alcsoport } \\
3 \\
\end{array}$ & $\mathrm{~B}$ \\
\hline & $\mathrm{s}_{1}$ szignifikanciája & $\mathrm{Sz}_{1}$ & 1,294 & 1,50 & $\begin{array}{c}\text { Sajátérték szignif- } \\
\text { ikanciája }\end{array}$ & A \\
\hline & $\mathrm{s}_{2}$ szignifikanciája & $\mathrm{Sz}_{2}$ & 0,695 & 1,8284 & $\begin{array}{c}\text { Sajátérték szignif- } \\
\text { ikanciája }\end{array}$ & B \\
\hline & s$_{3}$ szignifikanciája & $\mathrm{Sz}_{3}$ & - & 0,4858 & Sajátérték szignif- & $\mathrm{B}$ \\
\hline
\end{tabular}




\begin{tabular}{|c|c|c|c|c|c|c|}
\hline & & & & & ikanciája & \\
\hline & Szélesség a max. felénél $\mathrm{s}_{1}$ & $\eta_{1}$ & 1,294 & 1,50 & $\begin{array}{l}\text { Sajátérték körüli } \\
\text { szóródás }\end{array}$ & $\mathrm{B}$ \\
\hline & Szélesség a max. felénél $s_{2}$ & $\eta_{2}$ & 1,529 & 4,571 & $\begin{array}{l}\text { Sajátérték körüli } \\
\text { szóródás }\end{array}$ & $\mathrm{B}$ \\
\hline & Szélesség a max. felénél $\mathrm{s}_{3}$ & $\eta_{3}$ & - & 1,846 & $\begin{array}{l}\text { Sajátérték körüli } \\
\text { szóródás }\end{array}$ & $\mathrm{B}$ \\
\hline \multirow[t]{2}{*}{$\begin{array}{c}\text { Lorentz- fv. } \\
\text { deriváltja }\end{array}$} & $\begin{array}{l}\text { Lorentz- gbe deriv. széles- } \\
\text { ség }\end{array}$ & $\mathrm{b}_{\mathrm{d}}$ & 1,3 & 3,4 & Szóródási szélesség & $\mathrm{B}$ \\
\hline & Lorentz- gbe deriv. magas. & $\mathrm{h}_{\mathrm{d}}$ & 1,65 & 1,4 & Szóródási magasság & $\mathrm{A}$ \\
\hline \multirow{3}{*}{$\begin{array}{l}\text { Lorentz- } \\
\text { függvény } \\
\text { integrálja }\end{array}$} & $K$ & $K_{1}$ & 1,85 & 4,1 & $\begin{array}{l}\text { Eredm.-hez szüks. } \\
\text { hallg. száma }\end{array}$ & $\mathrm{B}$ \\
\hline & $r=r_{1} / c$ & $r_{1}$ & 2,1 & 2,5 & Növekedési sebesség & $\mathrm{A}$ \\
\hline & $c$ & $c$ & 1,05 & 0,4 & $\begin{array}{l}\text { Vegyes hatású } \\
\text { paraméter }\end{array}$ & - \\
\hline Pontszám & Nyert szemp.-k darabszáma & $\Sigma$ & 26 & 5 & $\begin{array}{l}\text { Összesítésben nyer- } \\
\text { tes }\end{array}$ & $\mathrm{B}$ \\
\hline
\end{tabular}

